\title{
PENINGKATAN AKTIVITAS BELAJAR EKONOMI DALAM PEMBELAJARAN COOPERATIVE LEARNING TYPE STUDENT TEAMS ACHIEMENTS DIVISION (STAD) PADA SMPN 14 PADANG
}

\author{
Sri Wahyuni \\ Dosen Program Studi Pendidikan Ekonomi STKIP- PGRI Sumbar \\ Jl. Gunung Pangilun No.1, Padang Sumatera Barat \\ Email: Ajeng_sriwahyuni@gmail.com
}

Submitted: 2012.09.17 Reviewed: 2012.09.28 Accepted: 2012.10.18

http://dx.doi.org/10.22202/economica.2012.v1.i1.110

\begin{abstract}
This research aims to obtain a picture of how STAD model cooperative learning can enhance students' learning activities in class VII Economic IPS SMP 14 Padang. Type of research is a class act. Which in this study consisted of two cycles and each cycle there are three meetings.These results indicate activity of students in cycle one and two respectively silkus increased. In cycle one of the nine descriptors six of which have exceeded $56 \%$ of that increase students' skills in listening, describing, questioning, discussing, responding and concluded while the ability to observe, describe and convey the idea has actually been performing well but has not reached $65 \%$. While in the second cycle of the nine descriptors each is performing well.

Abstrak

Penelitian ini bertujuan untuk memperoleh gambaran tentang bagaimana pembelajaran kooperatif model STAD dapat meningkatkan aktivitas belajar siswa di kelas VII Ekonomi IPS SMP 14 Padang. Jenis penelitian adalah tindakan kelas. Yang dalam penelitian ini terdiri dari dua siklus dan setiap siklus ada tiga hasil meetings.These menunjukkan aktivitas siswa pada siklus satu dan dua masing-masing silkus meningkat. Dalam satu siklus dari sembilan deskriptor enam di antaranya telah melebihi $56 \%$ dari keterampilan yang meningkat siswa dalam mendengarkan, menjelaskan, mempertanyakan, membahas, menanggapi dan menyimpulkan sementara kemampuan untuk mengamati, menjelaskan dan menyampaikan ide sebenarnya sudah terlaksana dengan baik tetapi memiliki tidak mencapai 65\%. Sementara di siklus kedua dari sembilan deskriptor setiap berkinerja baik.
\end{abstract}

Keywords: Cooperative Learning Students Teams Achiements Division 


\section{PENDAHULUAN}

Sistem pendidikan di Indonesia ternyata telah mengalami banyak perubahan. Perubahan-perubahan itu terjadi karena telah dilakukan berbagai usaha pembaharuan dalam pendidikan sehingga semakin mengalami kemajuan. Sejalan dengan kemajuan tersebut, maka dewasa ini pendidikan di sekolahsekolah telah menunjukkan perkembangan yang sangat pesat. Perkembangan itu terjadi karena terdorong adanya pembaharuan tersebut, sehingga di dalam pengajaranpun guru selalu ingin menemukan metode dan peralatan baru yang dapat memberikan semangat belajar bagi semua siswa. Bahkan secara keseluruhan dapat dikatakan bahwa pembaharuan dalam sistem pendidikan yang mencakup seluruh komponen yang ada.

Pembangunan di bidang pendidikan barulah ada artinya apabila dalam pendidikan dapat dimanfaatkan sesuai dengan kebutuhan masyarakat dan bangsa Indonesia yang sedang membangun. Pada hakekatnya kegiatan belajar mengajar adalah suatu proses interaksi atau hubungan timbal balik antara guru dan siswa dalam satuan pembelajaran. Guru sebagai salah satu komponen dalam proses belajar menganjar merupakan pemegang peran yang sangat penting. Guru bukan hanya sekedar penyampai materi saja, tetapi lebih dari itu guru dapat dikatakan sebagai sentral pembelajaran.

Sebagai pengatur sekaligus pelaku dalam proses belajar mengajar, gurulah yang mengarahkan bagaimana proses belajar mengajar itu dilaksanakan. Karena itu guru harus dapat membuat suatu pengajaran menjadi lebeh efektif juga menarik sehingga bahan pelajaran yang disampaikan akan membuat siswa merasa senang dan merasa perlu untuk mempelajari bahan pelajaran tersebut.

Berbagai perlakuan dapat dilakukan siswa berkaitan dengan keberadaan pengajaran yang masih banyak dilakukan secara konvensional (pembelajaran terpusat pada guru). Perasaan jenuh yang dialami siswa dengan pembelajaran seperti itu mengurangi konsentrasi belajar siswa dan mengalihkan perhatiannya pada hal-hal yang dapat menghilangkan kejenuhan tersebut, seperti mengobrol di kelas, melamun, mengerjakan tugas mata pelajaran selain ekonomi bahkan sengaja tidur di kelas.

Apabila guru bisa melakukan aktifitas belajar yang menggairahkan maka siswa cendrung berpartisipasi aktif, dan dapat disimpulkan bahwa keberhasilan belajar siswa akan dapat kita lihat salah satunya keaktifan siswa tersebut karena siswa yang aktif akan mencoba menemukan, mendalami sendiri serta berdiskusi dengan teman sehingga materi pelajaran akan lebih lama diingat.

Atas tuntutan diatas diperlukan suatu strategi pembelajaran yang dapat mengaktifkan siswa secara optimal. Guru sebagai salah satu pendukung dalam proses pembelajaran harus mampu menciptakan kondisi sedemikian rupa sehingga dapat merangsang siswa untuk aktif belajar. Guru harus berusaha melibatkan siswa secara aktif dan meningkatkan motivasi dalam proses pembelajaran.

Dalam pembelajaran STAD siswa dibagi menjadi kelompok-kelompok kecil yang terdiri dari empat lima orang yang berbeda kemampuannya dan mereka saling bekerja sama untuk mempelajari materi pelajaran dan tugas-tugas yang diberikan guru di dalam kelompoknya. Selesai mempelajari materi maka mereka diberi kuis dan mereka tidak dibenarkan kerja sama dengan kelompoknya ataupun dengan anggota kelompok lain. Hasil kuis tersebut dikumpulkan untuk menjadi hasil kemampuan kelompok. Jadi dalam STAD siswa-siswa tidak hanya mengandalkan teman pintar saja untuk menjadi kelompok terbaik setiap anggota akan bekerja dan berusaha bersama-sama.

Dalam pembelajaran STAD terjadi hubungan saling menguntungkan diantara kelompok yang melahirkan rasa ingin tahu serta kemandirian sehingga bisa meningkatkan keaktifan siswa dalam pembelajaran Ekonomi. Berdasarkan uraian tersebut maka rumusan penelitian ini adalah: Peningkatan Aktivitas Belajar Ekonomi Dalam Pembelajaran Cooperative Learning Type Student Teams Achiements Division (STAD) Pada SMPN 14 Padang.

\section{LANDASAN TEORI Hasil Belajar}

Hasil belajar adalah suatu yang diperoleh setelah melakukan kegiatan belajar. Hasil belajar dari aspek kognitif merupakan kemampuan siswa dalam bidang pengetahuan, 
pemahaman, penerapan analisis dan sintesis. Untuk membuat keputusan penilaian setiap individu, banyak diperlukan informasi yang relevan.

Menurut Gagne dalam Sudjana (1992:22) hasil belajar adalah kemampuankemampuan yang dimiliki siswa setelah mengalami proses pembelajaran. Sedangkan menurut Sudjana ada lima kategori dalam belajar yakni, informasi verbal, keterampilan intelektual, strategi kognitif, sikap dan keterampilan motorik. Dalam syistem pendidikan nasional rumusan tujuan pendidikan, baik tujuan kurikuler maupun tujuan instruksional menggunakan klasifikasi hasil belajar, dari bunyamin Bloom dalam Sudjana (1992:23) yang secara garis besar dibagi menjadi tiga ranah yaitu ranah kognitif, afektif dan psikomotor.

Ranah kognitif biasanya berkenaan dengan hasil belajar intelektual yang terdiri dari enam aspek yaitu pengetahuan, pemahaman, aplikasi, analisis, sintesis, dan evaluasi. Ranah afektif berkenaan dengan sikap yang terdiri dari lima aspek yaitu penerimaan, jawaban atau reaksi, penilaian, organisasi dan internalisasi. Ranah psikomotor berkenaan dengan hasil belajar keterampilan dan kemampuan bertindak. Ada enam aspek psikomotor yaitu gerakan rileks, keterampilan gerakan dasar, kemampuan perpektual, ketetapan, gerakan keterampilan kompleks, gerakan aspiratif, dan gerakan interprestatif, sedangkan aspek afektif berkaitan dengan emosi seperti perasaan, apresiasi, antusiasme, motivasi dan sikap.

Adapun tujuan penilaian menurut Arikunto (1991:7) adalah mengetahui siswa mana yang berhak melanjutkan pelajaran karena telah menguasai materi dan siswa mana yang harus mengulang materi pelajaran, serta untuk mengukur sejauh mana ketercapaian tujuan instruksional oleh siswa. Hasil belajar yang dikuasai sesuai dengan target adalah $65 \%$ untuk individu dan klasikal adalah $85 \%$.

Dalam penggunaan Model Students Teams Achievements (STAD) peserta didik dituntut bekerja sendiri-sendiri. Mereka masing-masing mempertanggung jawabkan apa yang telah dibuat, guru berusaha mencari yang terbaik dan bertanggung jawab dalam suatu proses pertumbuhan. Guru dan peserta didik saling mengajar apa yang menjadi tujuannya masing-masing. Sehingga penilaian kegiatan belajar dan nilai hasil dapat dilakukan dengan menggunakan evaluasi yang berupa tes.

\section{Aktifitas Belajar}

Aktivitas belajar adalah aktivitas yang bersifat fisik maupun mental, dan kedua aktivitas belajar itu harus selalu berkait. Menurut Paiget (2001:98) : seorang anak itu berfikir sepanjang ia berbuat. Tanpa berbuat berati anak itu tidak berpikir. Untuk itu agar anak berpikir sendiri maka harus diberi kesempatan untuk berbuat sendiri. Berpikir pada taraf verbal baru akan timbul setelah anak itu berpikir pada taraf perbuatan.

Adapun jenis-jenis aktivitas dalam belajar menurut Paul B. Diedrich dalam sardiman (2001: 99) dapat diklasifikasikan sebagai berikut:

a. Visual activities, yang termasuk didalamnya membaca, memperhatikan gambar demonstrasi, percobaan pekerjaan orang lain.

b. Oral activities, seperti: menyatakan, merumuskan, bertanya, memberi saran, mengeluarkan pendapat, mengadakan wawancara, diskusi, interupsi

c. Writing Activities, seperti: menulis, cerita, karangan, laporan, menyalin, angket

d. Listening Activities, seperti: mendengarkan, uraian, percakapan, diskusi, music dan pidato

e. Drawing activities, seperti: menggambar, membuat grafik, peta dan diagram

f. Motor Actvities, Seperti: melakukan percobaan, membuat konstruksi, model, mereparasi, bermain, berkebun, dan beternak.

g. Mental Activities, Seperti: mengingat, memecahkan soal, menganalisis, melihat hubungan, mengambil keputusan.

h. Emosional Activities, Seperti: menaruh minat, merasa bosan, gembira, bersemangat, bergairah, barani, tenang, gugup.

Aktivitas di sekolah cukup kompleks dan bervariasi. Jika kegiatan atau aktiviatas tersebut dapat dilaksanakan di sekolah dengan baik, proses aktivitas tersebut dapat dilaksanakan disekolah dengan baik. Aktivitas belajar siswa yang maksimal akan mempelancar tujuan pembelajaran yang hendak dicapai. 


\section{Belajar aktif}

Seorang siswa dapat dikatakan telah belajar aktif apabila siswa tersebut dalam proses pembelajaran sudah melakukan sebagian besar pekerjaannya, mampu dan berani mengemukakan pendapat dan mengajukan pertanyaan, membuat kesimpulan, menerapkan apa yang dipelajari, mendiskusikan serta mengajukannya pada orang lain.

Belajar merupakan proses perubahan dari hasil interaksi dengan lingkungan untuk memenuhi kebutuhan fisik, mental dan spiritual. Perubahan tersebut mencakup, aspek tingkah laku, keterampilan dan pengetahuan. Seseorang akan aktif belajar apabila dia memiliki motivasi, dan siswa aktif akan biasa melakukan sebagian besar pekerjaannya, dan belajar merupakan suatu proses dalam memperoleh pengalaman dan pengetahuan baru yang menghasilkan perubahan tingkah laku yang bersifat tetap.

Seseorang yang telah belajar akan mengalami perubahan tingkah laku dan pengetahuan kea rah yang lebih baik dibandingkan sebelum dia mengalami proses belajar.

\section{Pembelajaran Cooperative (Cooperative Learning)}

Pembelajaran kooperatif merupakan model pembelajaran dengan kelompok. Siswa dalam pembelajaran ini diharapkan dapat bekerja sama dan saling membantu dengan anggota kelompoknya untuk mempelajari materi pelajaran dan tugas-tugas yang diberikan guru.

Menurut Mulim Ibrahim (2003:3): model pembelajaran komperatif adalah menuntut kerja sama siswa dan saling ketergantungan dalam struktur, tujuan dan hadiah". Jadi dengan kerja kelompok dapat mengaktifkan siswa, sebab dalam kelompok mereka akan bekerja sama, dan berdiskusi untuk mengerjakan tugas.

Pembelajaran kooperatif mempunyai beberapa manfaat, menurut Anita Lie dalam Anam (2002:2) adalah: (1) siswa dapat meningkatkan kemampuannya untuk bekerja sama dengan siswa lain (2) Siswa mempunyai lebih banyak kesempatan untuk menghargai perbedaan (3) Partisipasi siwa dalam proses belajar meningkat (4) Mengurangi kecemasan siswa (kurang percaya diri) (5) meningkatkan motivasi, harga diri dan sikap positif (6) Meningkatkan prestasi siswa.

Peranan guru dalam pembelajaran kooperatif sangat kompleks. Guru sebagai fasilitator juga sebagai manajer dan konsultan dalam memberdayakan kerja kelompok siswa, guru harus bisa memotivasi siswa untuk aktif dan berpartisipasi dalam kegiatan belajar. Pada pembelajaran cooperative dikenal enam fase yang harus dilalui oleh guru dan siswa yang terlibat dalam proses dan pembelajaran. Fase tersebut ditujukan pada table dibawah ini

\section{Tabel 1. Fase-Fase Pembelajaran Kooperatif}

\begin{tabular}{|c|c|}
\hline FASE & TINGKAH LAKU GURU \\
\hline $\begin{array}{l}\text { Fase } 1 \\
\text { Menyampaikan tujuan dan motivasi } \\
\text { siswa }\end{array}$ & $\begin{array}{l}\text { Juru menyampaikan semua tujuan pembelajaran yang ingin dicapai pada } \\
\text { embelajaran tersebut dan memotivasi siswa belajar }\end{array}$ \\
\hline $\begin{array}{l}\text { Fase } 2 \\
\text { Menvaiikan Informas }\end{array}$ & swa dengan jalan demonstrasi atau \\
\hline $\begin{array}{l}\text { Fase } 3 \\
\text { Mengorganisasikan }\end{array}$ & $\begin{array}{l}\text { Guru menjelaskan kepada siswa bagaimana caranya membentuk kelompok } \\
\text { belajar dan membantu setiap kelompok agar melakukan transisi secara efektif }\end{array}$ \\
\hline npok belajar & \\
\hline $\begin{array}{l}\text { Fase } 4 \\
\text { Membimbing kelompok kerja }\end{array}$ & $\begin{array}{l}\text { Guru membimbing kelompok-kelompok belajar pada saat mereka } \\
\text { mengerjakan tugas mereka }\end{array}$ \\
\hline Fase 5 & Guru mengevaluasi hasil belajar tentang materi yang telah dipelajari atau \\
\hline & \\
\hline Fase 6 & Guru mencari cara-cara untuk menghargai baik upaya maupun hasil belajar \\
\hline Memberikan penghargaan & \\
\hline
\end{tabular}

\section{Model Pembelajaran "Student Teams Achievement Division”}

Salah satu model pendekatan dalam pembelajaran kooperatif adalah Student Teams Achiement Division (STAD) artinya adalah 
kelompok siswa yang berprestasi, pada masing-masing divisi atau kelompok. Jadi setiap kelompok akan berusaha menjadi yang terbaik diantara kelompok yang ada. Model pembelajaran tipe STAD, siswa dibagi menjadi kelompok-kelompok kecil yang terdiri 4-5 orang dengan kemampuan yang berbeda-beda seperti yang dikemukakan oleh Slaving:71

STAD is one the simplest observation of all cooperative learning methods, and is good model to begin with for teachers who are new to the cooperativeapproach. Overview STAD consists of five major improvement scores, and team recognition. (STAD adalah salah satu metode pembelajaran kooperatif yang paling sederhana, dan merupakan model yang bagus sebagai permulaan bagi guru yang baru terhadap pendekatan kooperatif. STAD terdiri dari lima komponen utama: presentasi kelas, kuis, nilai perkembangan individu, dan penghargaan kelompok) Jadi model pembelajaran STAD adalah pembelajaran dalam kelompokkelompok kecil yang terdiri atas empat atau lima siswa dalam setiap kelompok. Setiap kelompok akan bekerja sama dan saling membantu dalam mengerjakan tugas yang diberikan. Setelah itu mereka diberi kuis atau tes tentang tugas yang telah diberikan. Siswa tidak dibenarkan saling membantu pada waktu tes atau kuis. Hasil tes dikumpulkan menjadi dasar hasil kelompok. Nilai yang dicapai masing-masing kelompok diberi pengakuan dengan mengumumkan didepan kelas.

\section{Komponen-komponen STAD}

a. Persentasi kelas

Materi STAD diperkenalkan dalam sebuah presentasi kelas. Paling sering diadakan perintah langsung atau diskusi oleh guru, tetapi bisa masuk pada persentasi audio visual. Presentasi kelas dalam STAD berbeda dari peragaan biasa hanya dalam hal bahwa mereka harus secara jelas terfokus pada unit STAD. Dalam hal ini, siswa menyadari mereka harus memperhatikan selama presentasi kelas, karena melakukan hal itu akan membantu mereka mengerjakan kuis dengan baik, nilai kuis menentukan nilai kelompok.

b. Kelompok

Kelompok dibentuk dari empat atau lima siswa yang memiliki golongan campuran dalam kelas seperti kemampuan akademis, jenis kelamin, dan ras atau etnik. Fungsi utama dari kelompok adalah untuk meyakinkan bahwa semua anggota kelompok sedang belajar, dan lebih khususnya mempersiapkan anggotanya melakukan kuis dengan baik. Setelah guru menampilkan materi, kelompok bertemu untuk mempelajari lembar kerja atau materi yang lain. Paling sering pelajaran akan melibatkan siswa mendiskusikan masalah bersama, membandingkan jawaban, dan memperbaiki kesalah pahaman jika teman sekelompok membuat kesalahan.

Kelompok ciri yang paling penting dalam STAD. Pada setiap hal, perhatian ditempatkan pada anggota kelompok dalam melakukan yang terbaik dari mereka untuk kelompok, dan kelompok melakukan yang terbaik untuk membentuk anggotanya. Kelompok memberikan dukungan untuk penampilan akademis yang penting untuk pelajaran, dan memberikan perhatian yang menguntungkan dan rasa hormat yang penting untuk hasil sebagai hubungan dalam kelompok, penghargaan diri dan penerimaan siswa.

c. Kuis

Setelah kira-kira 12 periode presentasi guru dan 1-2 periode pratek kelompok, siswa melakukan kuis individu. Siswa tidak diizinkan untuk selain membantu satu sama lain selama kuis. Jadi, setiap siswa secara pribadi bertanggung jawab untuk mengetahui materi.

d. Nilai Perkembangan Individu

Adalah untuk memberikan setiap siswa tujuan penampilan yang bisa dicapai jika ia bekerja lebih giat dan menampilkan yang lebih baik dari sebelumnya. Siswa bisa mengumpulkan poin maksimum untuk kelompoknya dalam system penilaian. Setiap siswa diberikan nilai dasar diperoleh dari rata-rata penampilannya yang lalu pada kuis yang sama. Kemudian siswa mendapatkan poin untuk kelompoknya berdasarkan derajat nilai kuis mereka yang melebihi nilai dasar mereka.

e. Penghargaan Kelompok

Kelompok boleh mendapatkan sertifikat atau penghargaan yang lain jika nilai ratarata mereka melebihi criteria tertentu. Nilai 
kelompok siswa boleh digunakan untuk menentukan lebih dari $20 \%$ tingkat mereka.

\section{Langkah-langkah Pembelajaran STAD}

Dalam Pembelajaran STAD terdapat enam langkah yang harus dilalui yaitu

1. Membentuk kelompok yang anggotanya empat atau lima orang secara heterogen (campuran menurut prestasi, jenis kelamin, suku dan lain-lain.

2. Guru menyajikan pelajaran (analisis materi atau buku bacaan)

3. Guru memberikan tugas pada kelompok untuk didiskusikan oleh anggota kelompok

4. Guru memberikan kuis atau pertanyaan kepada seluruh siswa, dan pada saat menjawab kuis atau pertanyaan tidak boleh saling membantu

5. Nilai Individu siswa dikumpulkan menjadi nilai kelompok yang akan dijadikan nilai dasar kemajuan kelompok

6. Nilai rata-rata kelompok yang tertinggi akan diberi pengakuan seperti diumumkan didepan kelas dan diberi pujian dan penghargaan.

Berdasarkan rumusan masalah maka hipotesis dalam penelitian ini adalah "Model pembelajaran tipe Student Teams Achievements Division (STAD) dapat meningkatkan aktivitas dan hasil belajar siswa kelas VII.1 SMPN 14 Padang.

\section{METODOLOGI PENELITIAN}

Jenis penelitian ini adalah penelitian tindakan kelas (Classroom Action Research), dimana dalam kelas diberi tindakan (action). Dalam penelitian ini dilakukan observasi didalam kelas terhadap aktivitas siswa selama berlangsung proses belajar mengajar. Penelitian yang dilakukan adalah model spiral, satu putaran spiral satu siklus terdiri dari langkah-langkah perencanaan (plan), tindakan (action), pemantauan (observation) dan refleksi. Pada penelitian ini terdiri dari dua siklus. Satu Siklus terdiri dari tiga pertemuan.

\section{Prosedur Penelitian STAD}

1. Refleksi Awal

Dalam Refleksi awal ini kita melihat apa saja permasalah yang hihadapi dalam pembelajaran sebelumnya, yaitu siswa fasif dalam pembelajaran.
2. Siklus I

a. Perencanaan

Sebelum penelitian dilakukan, maka disusunlah perencanaan berbagai hal:

1) Mempersiapkan rencana pembelajaran(RPP), 2) Menyediakan lembaran kerja siswa, analisis materi ajar, 3) Membut lembaran observasi

b. Tindakan (Action)

1) Guru menjelaskan model pembelajaran STAD, 2) Siswa dibagi dalam beberapa kelompok kecil yang terdiri dari empat sampai 5 orang, 3) Guru memberikan ringkasan materi, 4) Guru mengacak beberapa kelompok untuk membacakan hasil diskusi, 5) Siswa diberi tes atau kuis, 4) Nilai individu siswa dikumpilkan menjadi nilai kelompok, 5) Nilai Kelompok yang tinggi diberi pengakuan

c. Pemantauan (observasi)

Mencatat aktivitas siswa selama berlangsung proses belajar mengajar. Data pada tabel disusun berdasarkan data pada lembaran pengamatan.

d. Refleksi

Data yang diperoleh diolah secara kuantitatif (persentase) dan secara Kualitatif (deskripsi dengan kata-kata)

\section{Siklus II}

\section{a. Perencanaan}

Untuk siklus II masih dirasakan beberapa perbaikan dengan tindak merubah langkah-langkah umum yang dilakukan pada siklus pertama.

b. Tindakan

Untuk tindakan siklus kedua yang akan dilakukan adalah: 1) Setiap kelompok diberi tugas baca materi yang akan didiskusikan 2) Kemudian diambil nomor secara acak untuk mempersentasikan hasil diskusi kelompoknya, 3) Diberi setiap kesempatan tiap kelompok untuk bertanya atau tanggapan, 4) Membuat kesimpulan, 5) Mengadakan kuis dan tes, 6) Hasil kuis dikumpulkan setiap kelompok, nilai kelompok tertinggi diberi penguatan (hadiah) didepan kelas.

c. Pemantauan

Hal yang diamati siklus kedua sama dengan yang dilakukan siklus pertama

d. Refleksi 
Hasil yang dicapai dibandingkan dengan siklus pertama, apakah ada kemajuan atau tidak, sehingga pada siklus kedua ini akan diperoleh gambaran apakah penelitian sesuai dengan tujuan yang dirumuskan atau tidak

\section{PEMBAHASAN}

\section{A. Hasil Penelitian}

\section{Tabel 2. Tingkat Perubahan Aktivitas Siswa pada Siklus I}

\begin{tabular}{|c|c|c|c|c|c|c|c|}
\hline \multirow{2}{*}{ No } & \multirow{2}{*}{ Aktivitas Belajar IPS Ekonomi } & \multicolumn{2}{|c|}{ Pertemuan 1} & \multicolumn{2}{|c|}{ Pertemuan 2} & \multicolumn{2}{|c|}{ Pertemuan 3} \\
\hline & & Jlh & $\%$ & Jlh & $\%$ & Jlh & $\%$ \\
\hline 1 & Siswa yang mampu mengerti & 8 & 22,9 & 15 & 42,9 & 22 & 62,9 \\
\hline 2 & Siswa yang mampu mengamati & 7 & 20,0 & 15 & 42,9 & 20 & 57,1 \\
\hline 3 & Siswa yang mampu menjelaskan & 6 & 17,1 & 14 & $\mathbf{4 0 , 0}$ & 19 & 54,3 \\
\hline 4 & $\begin{array}{l}\text { Siswa yang mampu memberi } \\
\text { contoh }\end{array}$ & 9 & 25,7 & 16 & 45,7 & 23 & 65,7 \\
\hline 5 & $\begin{array}{l}\text { Siswa yang mampu bertanya dan } \\
\text { kerja sama }\end{array}$ & 5 & 14,3 & 17 & 48,6 & 23 & 65,7 \\
\hline 6 & Siswa yang mampu mendiskusikan & 6 & 17,1 & 10 & 28,6 & 15 & 42,9 \\
\hline 7 & $\begin{array}{l}\text { Siswa yang mampu menyampaikan } \\
\text { gagasan }\end{array}$ & 5 & 14,3 & 8 & 22,9 & 14 & 40,0 \\
\hline 8 & $\begin{array}{l}\text { Siswa yang mampu memberi } \\
\text { tanggapan }\end{array}$ & 5 & 14,3 & 8 & 22,9 & 16 & 45,7 \\
\hline 9 & Siswa yang mampu menyimpulkan & 5 & 14,3 & 10 & 28,6 & 18 & 51,4 \\
\hline $\begin{array}{l}\text { pada } \\
\text { dimar } \\
\text { penin } \\
\text { klasik }\end{array}$ & $\begin{array}{l}\text { Dari Tabel 2. diatas terlihat ba } \\
\text { siklus I ini terdapat tiga pertem } \\
\text { a tiga pertemuan tersebut menga } \\
\text { gkatan namun belum mencapai se } \\
\text { al yaitu } 85 \% \text { siswa aktif dalam belaja }\end{array}$ & $\begin{array}{l}\text { wa } \\
\text { an, } \\
\text { mi } \\
\text { ara }\end{array}$ & $\begin{array}{l}\text { siswa p } \\
\text { sempurr } \\
\text { dilihat } \\
\text { belajarn } \\
\text { ketiga } 1 \\
\text { melebih }\end{array}$ & $\begin{array}{l}\text { ri p } \\
\text { umu } \\
\text { wala } \\
\text { seg } \\
\text { dari }\end{array}$ & $\begin{array}{l}\text { tase } \\
\text { a belu } \\
\text { n suda } \\
\text { nlah si } \\
\text { muan } \\
\text { criter } \\
\text { mlah s }\end{array}$ & $\begin{array}{l}\text { ripto } \\
\text { erlaks } \\
\text { da p } \\
\text { yan } \\
\text { ama, }\end{array}$ & $\begin{array}{l}\text { aktivitas } \\
\text { a secara } \\
\text { ngkatan } \\
\text { aktivitas } \\
\text { dua dan } \\
\text { d sudah }\end{array}$ \\
\hline
\end{tabular}

Tabel 3. Tingkat Perubahan Aktivitas Siswa Pada Siklus 2

\begin{tabular}{llcccccc}
\hline \multirow{2}{*}{ No } & \multirow{2}{*}{ Aktivitas Belajar IPS Ekonomi } & \multicolumn{2}{c}{ Pertemuan 5 } & \multicolumn{2}{c}{ Pertemuan 6 } & \multicolumn{2}{c}{ Pertemuan 7 } \\
\cline { 3 - 8 } & & Jlh & \% & Jlh & \% & Jlh & \% \\
\hline 1 & Siswa yang mampu mengerti & 24 & 68,6 & 27 & 77,1 & 28 & 80,0 \\
2 & Siswa yang mampu mengamati & 22 & 62,9 & 24 & 68,6 & 25 & 71,4 \\
3 & Siswa yang mampu menjelaskan & 20 & 57,1 & 21 & 60,0 & 24 & 68,6 \\
4 & Siswa yang mampu memberi contoh & 25 & 71,4 & 27 & 77,1 & 27 & 77,1 \\
5 & Siswa yang mampu bertanya dan kerja & 23 & 65,7 & 25 & 71,4 & 26 & 74,3 \\
& Sama & & & & & & \\
6 & Siswa yang mampu mendiskusikan & 20 & 57,1 & 22 & 62,9 & 24 & 68,6 \\
7 & Siswa yang mampu menyampaikan & 18 & 51,4 & 21 & 60,0 & 22 & 62,9 \\
& gagasan & & & & & & \\
8 & Siswa yang mampu memberi tanggapan & 20 & 57,1 & 22 & 62,9 & 24 & 68,6 \\
9 & Siswa yang mampu menyimpulkan & 21 & 60,0 & 24 & 68,6 & 28 & 80,0 \\
\hline
\end{tabular}

Dari Tabel 3. terlihat bahwa dari pertemuan lima sampai tujuh pada siklus kedua ini aktivitas belajar siswa sudah menunjukan peningkatan bila ditinjau dari ketuntasan aktivitas siswa secara klasikal.
Jumlah siswa yang tuntas bertambah, demikian pula dengan rata-rata kelas yang cenderung meningkat. Hal ini dapat dilihat dari nilai yang diperoleh pada siswa setiap kelompok pertemuan. 
Berdasarkan analisis data observasi penelitian yang dilakukan di SMPN 14 Padang, menunjukan bahwa penggunaan pembelajaran kooperatif model STAD dapat meningkatkan aktifitas siswa. Hal ini dapat dilihat dari meningkatnya keaktifan siswa dalam melakukan semua aktifitas siswa. Hal ini dapat dilihat dari meningkatnya keaktifan siswa dalam melakukan semua aktifitas belajar pada setiap siklus.

Dimana pada siklus I masing-masing aktifitas terjadi peningkatan dari Sembilan indicator yang ada yaitu kemampuan dalam mengerti $62,9 \%$, kemampuan mengamati $57,1 \%$, kemampuan menjelaskan54,3\%, kemampuan memberikan contoh $65,7 \%$, kemampuan bertanya dan bekerja sama $65,7 \%$, kemampuan berdiskusi 42,9\%, kemampuan menyampaikan gagasan $40 \%$, memberikan tanggapan $45,7 \%$, kemampuan menyimpulkan $51,4 \%$.

Pada siklus II masing-masing aktifitas yang ingin dicapai terjadi peningkatan dari Sembilan indicator yang ada yaitu kemampuan mengerti mengalami peningkatan 80,0 \%, kemampuan siswa mengamati terjadi peningkatan $71,4 \%$, kemampuan menjelaskan mengalami kenaikan 68,6\%, kemampuan memberikan contoh mengalami kenaikan sebesar $77,1 \%$, kemampuan bertanya dan bekerja sama mengalami kenaikan sebesar $74,3 \%$, kemampuan berdiskusi mengalami kenaikan sebesar 68,6\%, kemampuan menyampaikan gagasan mengalami kenaikan sebesar 62,9\%, memberikan tanggapan mengalami kenaikan sebesar 68,6\%, kemampuan menyimpulkan mengalami kenaikansebesar $80,0 \%$.

\section{PENUTUP}

Berdasarkan data dan pembahasan dapat diambil kesimpulan bahwa penerapan pembelajaran kooperatif model STAD yang dilakukan pada siklus I dan siklus II dapat meningkatkan aktivitas siswa khususnya mata pelajaran IPS Ekonomi. Hal tersebut dapat dilihat dari perubahan-perubahan aktifitas siswa pada setiap pertemuan ada peningkatan pada masing-masing siklus.

Dari hasil penelitian yang dilakukan sebaiknya guru harus teliti mendengarkan presentasi dari kelompok penyaji dan untuk meningkatkan hasil belajar siswa serta untuk meningkatkan keaktifan siswa dalam belajar maka guru sebaiknya menggunakan model pembelajaran Cooperative Learning Type Student Teams Achievements Division dalam pembelajaran Ekonomi.

\section{DAFTAR PUSTAKA}

10.22202/economica.2012.v1.i1.110

Abu, Ahmadi. (1994). Teknik Belajar yang Efektif. Jakarta: Rineka Cipta

Anam, Khairil. (2000). Buletin Peningkatan Mutu Pendidikan : Pelangi. Pendidikan Jakarta

Arikunto, Suharsimi. (1989). Dasar-Dasar Ilmu Pendidikan. Jakarta: Bina Aksara (1992). Pengelolaan kelas dan Siswa. Jakarta: Raja Grafindo Persada

(1995). Prosedur Penelitian suatu pendekatan Pratek. Jakarta: Rineka Cipta

Hamalik, Oemar. (2002). Proses Pembelajaran. Jakarta: Bumi Aksara

Muslim Ibrahim,dkk. (2000). Pembelajaran kooperatif. Surabaya: University Press

Koes, Supriyono. (2003). Strategi Pembelajaran. Jakarta: Bina Aksara

Sardiman. (2001). Internalisasi dan Motivasi Belajar Mengajar. Jakarta: Raja Grafindo Persada (2001). Belajar dan Faktor-Faktor Yang Mempengaruhinya. Jakarta: Rineka Cipta

Silberman, Melving. (2006). Active Learning 101 Cara Belajar Siswa Aktif. Bandung: Nusamedia. 